\title{
The assessment of ethics ${ }^{1}$
}

\author{
Clair Hughes \\ The University of Queensland \\ clair.hughes@uq.edu.au
}

Keywords: assessment, ethics, graduate attributes

\begin{abstract}
That Australian universities value the development of qualities broadly related to ethics is evidenced through their inclusion in institutional statements of graduate attributes (GA). Early GA implementation strategies largely emphasised the mapping of specific attributes against existing programmes or courses. There is now a growing acknowledgement that authentic implementation does not occur unless GAs are embedded in assessment. The assessment of GAs is a problematic and challenging task, a situation attributed partly to difficulties in conceptualising GAs in ways that facilitate their operationalisation in teaching and assessment and partly to inadequacies in the development of assessment strategies and instruments. For many academics, the moral dimension of ethics so intensifies the assessment challenge that they are often not assessed at all. While these difficulties are acknowledged, this paper argues the case for the explicit inclusion of ethics in course teaching and assessment plans and illustrates some of the contexts, including the student university learning experience, in which the development and assessment of ethics can be undertaken.
\end{abstract}

\section{Introduction}

Whether we consciously plan for ethical outcomes or not, they happen. We teach implicit lessons on ethics; we model ethical (or unethical) behaviour or reasoning, often unconsciously; and our practices deliver certain results, both to students and employees as well as to society. What we as universities and university employees do, deliver and produce has an impact. If we do not plan for desired impact, we can become "strategically tragic" - delivering undesirable consequences to the external world and society and to those internal to the university whom we serve as well (students and employees). (Moore, 2008, p. 1)

Universities have traditionally included the development of student integrity as an intrinsic, but sometimes implicit, component of their mission. In recent times, this aim has been explicated through reference to some form of ethical outcomes in the statements of GAs articulated by most Australian universities. The term 'graduate attribute' is commonly used in Australia to refer to the overarching outcomes of a programme of university study of several years duration. 'Graduate' or 'generic' attributes are in relatively common use in Australian and the United Kingdom (UK) and equate to the 'student learning outcomes' or 'programme outcomes' more commonly used in the United States (US) and some European educational curriculum documents.

The International Journal for Educational Integrity is available online at: http:// www.ojs.unisa.edu.au/journals/index.php/IJEI/

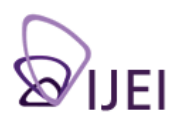


Policy expressions of GA usually imply a notion of application in relation to the ethical practices of a profession - To understand and apply ethical professional practices: a field of study - An awareness of and sensitivity to ethics and ethical standards on interpersonal and social levels, and within a field of study and/or profession: and, personal life - To respect, understand and apply ethical practices personally and professionally (italicised sections are extracts from Australian University Graduate Attribute Statements, The National Graduate Attribute Project [GAP] website).

Though policies employ expressions such as ethical practice, reasoning or understanding, the more general term ethics is used throughout this paper other than when citing the terminology of particular literature.

A recent study (The National GAP), funded by the Australian Learning and Teaching Council (ALTC) scoped the embedding of GAs in curriculum and teaching. Findings from this study supported Barrie's (2004) earlier proposition that assessment provides more convincing evidence of GA policy achievement than earlier input indicators such as the mapping of GA coverage against existing course or programme outlines, a practice found to be perfunctory or otherwise problematic (Sumsion \& Goodfellow, 2004).

\section{The problematic nature of the assessment of Graduate Attributes}

However, the assessment of GAs, especially when undertaken for summative purposes, is itself problematic (Hughes \& Barrie, forthcoming). Knight and Page's (2007) assertion that 'wicked' attributes, a category in which they include ethical practice, may not be amenable to assessment as it is conventionally understood. The conceptual and practical challenges often associated with this type of attribute are due to the fact that they:

- $\quad$ are usually represented by a combination of knowledge, skills, attitudes or dispositions and practices

- $\quad$ are seldom able to be fully specified

- $\quad$ develop slowly - progress may not be evident within the span of a single semester

- $\quad$ require descriptions of criteria and context for understanding of judgements of performance

- $\quad$ rarely lend themselves to reporting assessment judgements in terms of marks (summary from Knight \& Page, 2007, p. 11).

So, while ethics is considered an important attribute by many academics, when these intrinsic difficulties are considered in combination with other personal and contextual factors such as academics' lack of expertise or interest, and the prioritisation of subject content in an already crowded curriculum (Matchett, 2008), low levels of engagement with either the development or assessment of ethics is unsurprising. $A$ recent study (de la Harpe, Thomas, Dalton \& David, 2009) reported that Australian academics consistently ranked ethical practice second last (ahead of only Information and Communication Technology Literacy out of nine attributes listed) for emphases given to teaching and assessment and the confidence and willingness with which they approached these tasks.

\section{The importance of assessing ethics}

Matchett (2008, p. 27) however, while acknowledging the magnitude of such difficulties, argues against their acceptance as a justifiable excuse for the omission of ethics from curriculum and assessment as ethical questions are at the core of most disciplines. Knight and Page (2007) also identify disadvantages of failing to assess 
competencies such as 'ethical practice' as what is not assessed is not taken seriously by students or by teachers: employers seek information on such attributes from applicants: governments expect evidence that these attributes are promoted and assessed: and, assessment helps students and teachers identify ways of enhancing development (summary from Knight \& Page, 2007, p. 13).

Even among those who consider ethics an important attribute to be developed through the university experience, there is a belief such development will occur through socialisation and that intervention, such as explicit attention through teaching and assessment, is unnecessary. Of course, the socialisation model does hold true to some extent as what has been termed the hidden curriculum (Snyder, 1973) - nonacademic experiences and interactions with academics, administrators and peers shapes much of what students learn about ethical behaviour at university (Matchett, 2008). Implicit, socialisation approaches however ignore the strong relationship between ethics and cognition and this is the basis of the argument for a more overt and systematic approach to embedding ethics in curriculum and assessment. It should be noted that this discussion addresses ethics as a GA; the teaching of ethics as a field of study is a matter of adherence to the same general principles and practices of effective teaching and learning as apply to any discipline area and therefore beyond the more general focus of this paper.

\section{The assessment of ethics}

Embedding ethics in assessment involves decision-making in ways appropriate to a particular educational context or situation. These decisions involve the selection and articulation of learning outcomes, the ways in which students will provide evidence of their achievement of the learning objectives, the basis of assessment judgements and the ways in which students will be involved in the assessment process.

\section{Learning outcomes related to ethics}

One of the key problems in articulating ethics learning outcomes is that GAs both collectively and individually may be conceptualised in quite different ways. Barrie's (2006) research identified four distinct orientations to GAs. While the first, precursory, can be discounted as having any relevance to this discussion, the remaining three suggest possible alternatives for framing the outcomes of a curriculum with explicit attention to the development of ethics:

- Complementary - a generic skill set that is separate from and secondary to the learning of disciplinary knowledge: complementary to but not altering or interacting with disciplinary knowledge in any way.

- Translation - an ability to translate or apply disciplinary knowledge: closely connected with and shaped by the parallel discipline learning outcomes so not generic but characteristic of particular disciplines and allowing the application of discipline knowledge in the real world.

- $\quad$ Enabling - abilities that transcend disciplinary boundaries though initially developed within a disciplinary context; enable students to reshape and transform knowledge to meet new challenges in contexts far removed from that of the original discipline; intellectual and personal attributes that are the keys to enquiry and learning in many aspects of life, not just formal study. ${ }^{2}$

It is not unusual to find examples of a complementary or generic approach to the development of GAs such as the communication or problem-solving courses offered by student support service units. A complementary approach however, is rarely (and possibly never) extended to the development of ethics. 
Ethics-specific courses or subjects, usually identifiable through titles such as Legal Ethics, or Medical Ethics, emphasise translation types of learning outcomes.

Translation approaches which prioritise application to professional responsibility may also extend this conceptualisation into the area of enabling through the inclusion of references to broader societal outcomes. Steneck's (1999, p. 13) conceptualisation of ethics as encompassing (1) technology and society (2) engineering and society, and (3) ethical reasoning, and with outcomes related to an understanding of the interrelationships between technological development and the welfare of individuals, society, and the environment is an example of this.

The four areas of 'learning outcomes for ethical deliberation' summarised by Matchett (2008, p. 35 citing Ozar, 2001) correspond even more closely to Barrie's (2006) enabling conceptualisation:

1. Knowledge of:

A. an array of values, principles, and ideals

B. potential conflicts among those values, principles, and ideals

C. facts that are especially relevant to ethical decisions in specific areas

D. a core set of useful conceptual tools (for example, well established ethical theories) and the reasons for their selection.

2. Skills in:

A. multiple perspective taking

B. formulating arguments that are logical, careful, and clear

C. employing the tools identified in 1.D.

D. applying standards that are commonly expected in both ordinary and professional social roles

E. analysing, evaluating, or otherwise relating to any number of other tools and standards to those identified in 2.C and 1.D.

3. Motivation and conviction: that is, the conscious affirmation of and pattern of living habitually... in accord with (one's) moral or ethical judgements.

4. Implementation: that is, the practical and emotional ability to carry out the course of action that (one) has judged ought to be done and is motivated to do.

Each distinct orientation to ethics implies a particular approach to teaching and learning as well as assessment. The following discussion, in many respects, therefore applies to teaching and learning as well as to assessment based on the acceptance of Boud's (1998) assertion that a worthwhile assessment activity also serves as a worthwhile teaching and learning activity.

\section{Generating evidence of achievement}

Assessment is the making of judgements about the quality of learning based on consideration of evidence of achievement in relation to criteria and standards. The role of the teacher is to provide opportunities for students to generate evidence through assigning formal assessment tasks or through drawing student attention to other contexts (e.g. work placements, service learning, study abroad, student clubs or associations) in which evidence of learning may be generated. The student role is to generate appropriate evidence and make it available for judgement. This is generally undertaken by teachers, tutors, peers or students themselves, or by other stakeholders (industry representatives, workplace supervisors) who are assuming greater roles in assessment processes in some (mainly) professional programmes. 
Numerous methods are available for assessing the cognitive and affective dimensions of ethics in formal ways. In going beyond the traditional examination or essay, Balogh (2002) suggests alternatives such as responses to case studies, the recording of observations in media diaries, journals or logbooks, role plays, skits and debates. However, no specific form of assessment is inherently appropriate for any specific conceptualisation of ethics. A written examination could be used for each of Barrie's (2006) conceptualisations listed above but each examination 'instrument' would require a distinct set of student responses that would constitute qualitatively different forms of evidence of achievement. Validity would be assured by the extent to which the assessment task, and consequently the evidence generated, was aligned with intended learning outcomes (Biggs, 2002).

Steneck (1999) has illustrated an attempt to align Criteria (learning outcomes) and Assessment tools (tasks) in the integrated engineering ethics curriculum adopted by the University of Michigan. As Table 1 illustrates, in this course the assessment of ethics draws on a number of different strategies and techniques.

Table 1:

Extract from 'Criteria and assessment tools for engineering ethics' (Steneck, 1999, $p$. 13)

\begin{tabular}{|c|c|c|}
\hline & Criteria & Assessment tools \\
\hline $\begin{array}{l}\mathbf{G} \\
\mathbf{e} \\
\mathbf{n} \\
\mathbf{e} \\
\mathbf{r} \\
\mathbf{a} \\
\mathbf{l}\end{array}$ & $\begin{array}{l}\text { Technology and Society (TS): Under- } \\
\text { stand interrelationships between tech- } \\
\text { nological development and the welfare } \\
\text { of individuals, society, and the environ- } \\
\text { ment. } \\
\text { Engineering and Society (ES): under- } \\
\text { stand the responsibilities associated } \\
\text { with a professional career. } \\
\text { Ethical reasoning (ER): ability to analyse } \\
\text { and to formulate reasoned solutions to } \\
\text { dilemmas involving professional re- } \\
\text { sponsibility. }\end{array}$ & $\begin{array}{l}\text { Basic knowledge (BK): questions on ex- } \\
\text { aminations testing basic knowledge. } \\
\text { Reasoning abilities (RA): opportunities to } \\
\text { apply and to receive comments on the } \\
\text { use of standard reasoning tools. } \\
\text { Self-evaluation (SA): questioned about } \\
\text { preparation to assume professional } \\
\text { responsibilities. } \\
\text { Professional evaluation (PA): interview } \\
\text { questionnaires and other feedback } \\
\text { from engineering professionals. }\end{array}$ \\
\hline $\begin{array}{l}\text { D } \\
\text { e } \\
\text { s } \\
\text { i } \\
\text { g } \\
\text { n }\end{array}$ & $\begin{array}{l}\text { TS - detailed understanding of the societal } \\
\text { impact of the students design project } \\
\text { on society. } \\
\text { ED - detailed understanding of any profes- } \\
\text { sional issues raised by the student's } \\
\text { design project. } \\
\text { ER - ability to identify and resolve any ethi- } \\
\text { cal dilemmas raised by the student's } \\
\text { design project. }\end{array}$ & $\begin{array}{l}\text { BK - objective questions testing basic con- } \\
\text { cepts and key factual information. } \\
\text { RA - required ethics component for final } \\
\text { design projects based on four steps for } \\
\text { pursuing an ethical analysis of an engi- } \\
\text { neering problem. } \\
\text { SA - midcourse and end of term course } \\
\text { evaluations. }\end{array}$ \\
\hline
\end{tabular}

James, Hughes and Cappa (forthcoming) in Table 2 demonstrate a similar (enabling and aligned) approach applied to the assessment of a not dissimilar attribute - critical (legal) thinking. 
Table 2:

The alignment of learning outcomes and assessment of critical legal thinking (James et al., forthcoming)

\begin{tabular}{|c|c|c|c|}
\hline $\begin{array}{l}\text { Component of } \\
\text { critical legal } \\
\text { thinking }\end{array}$ & Critical knowledge & Critical skills & Critical disposition \\
\hline $\begin{array}{l}\text { Learning out- } \\
\text { come }\end{array}$ & $\begin{array}{l}\text { Articulate a thorough } \\
\text { understanding of criti- } \\
\text { cal legal knowledge, } \\
\text { being non-orthodox } \\
\text { knowledge about the } \\
\text { law and law's cultural, } \\
\text { philosophical, ideologi- } \\
\text { cal, practical, ethical, } \\
\text { social, political, and } \\
\text { environmental con- } \\
\text { texts. }\end{array}$ & $\begin{array}{l}\text { Exercise critical legal } \\
\text { skills, including com- } \\
\text { prehension, analysis, } \\
\text { evaluation, justification } \\
\text { and synthesis skills, } \\
\text { as well as legal re- } \\
\text { search skills and legal } \\
\text { writing skills. }\end{array}$ & $\begin{array}{l}\text { Demonstrate a critical } \\
\text { disposition, being a } \\
\text { tendency to self-reflect } \\
\text { and change one's } \\
\text { views when required, } \\
\text { and a willingness to } \\
\text { question orthodoxy } \\
\text { and challenge igno- } \\
\text { rance and injustice } \\
\text { when appropriate. }\end{array}$ \\
\hline $\begin{array}{l}\text { Assessment } \\
\text { activity }\end{array}$ & $\begin{array}{l}\text { Weekly online quiz } \\
\text { (summative). }\end{array}$ & $\begin{array}{l}\text { Final 'closed book' } \\
\text { examination of } 90 \text { min- } \\
\text { utes. Items drawn from } \\
\text { critical exercises in } \\
\text { Learning Guide. }\end{array}$ & $\begin{array}{l}\text { Reflective essay on a } \\
\text { critical incident from } \\
\text { the course that con- } \\
\text { tributed in some way } \\
\text { to the development of } \\
\text { critical disposition. }\end{array}$ \\
\hline
\end{tabular}

As the assessment examples in Table 2 illustrate, evidence of achievement of the cognitive dimensions of learning may be generated through familiar tasks such as a quiz or contextually appropriate formal examination. However, the affective dimensions of attributes such as ethics pose a different type of assessment challenge. The critical incident reflective essay task designed to assess Critical disposition was selected because of the strength of Knight's (2002) argument that some aspects of student achievement such as disposition or behavioural intentions can not be warranted in the normal way through traditional or formal assessment. Instead he proposes that students are enabled 'to lay powerful claims to achievement which they could substantiate with material drawn from (sources such as) learning portfolios' (ibid 7) or reflective journals. This approach allows the assessment of ethics to be based not only on evidence generated by students as a response to the formal assessment tasks but also permits the inclusion of evidence generated as they observe or confront authentic ethical dilemmas and apply their knowledge and cognitive skills. The reflective task assigned effectively requires students to make a claim that they have developed a critical disposition and to offer evidence in support of that claim.

Knight (2002) stipulates that the success of such an approach is dependent on a number of factors including many opportunities for low stakes formative assessment, the provision of effective feedback, the development of grade indicators including threshold descriptors to complement the learning outcomes and the development of student capacity for self and peer assessment. Alverno College in the US is a frequently cited example of this approach in practice (Loaker, 2000). 


\section{The basis of assessment judgements}

The development of grade indicators or threshold descriptors to be used as the basis for the assessment of ethics has been approached in various ways. Kohlberg et al.'s (1983) 'Stages of moral development,' and Perry's (1970) 'Scheme of intellectual and ethical development' are commonly cited resources specific to this area. In addition, the more general Bloom's taxonomies in the cognitive (Krathwohl, 2002) and affective (Krathwohl, Bloom \& Masia, 1964) domains are applicable in articulating the basis for assessment judgements. The Association of American Colleges and Universities (2009) is supporting a collaborative project to develop what they refer to as metarubrics, one of which is for ethical reasoning. It is comprised of five criteria: (1) Ethical self-awareness, (2) Ethical issue recognition, (3) Understanding different ethical perspectives/concepts, (4) Application of ethical perspectives/concepts, and (5) Evaluation of different ethical perspectives/concepts. Four standards or levels are described for each of these criteria. At the time of writing the ethical reasoning rubric is in draft form with feedback invited which may address some of the drawbacks common to rubrics in which the distinction between levels is determined by a single word in each verbal standard - hence Ethical perspectives/concepts may be applied in fully, adequately, partially, or minimally accurate ways - a distinction whose meaning is unlikely to be shared by those who have no opportunity for some form of moderation or access to exemplars.

\section{The role of students}

An active role for students in the assessment process is essential for successful outcomes of any programmes seeking to develop ethics. Students will only develop ethical sensitivity, reasoning or practice through opportunities to consider the ethical implications of their own and others' actions; to apply frameworks and processes to ethical decision-making and to reflect on and evaluate the basis of their own ethical choices in a range of authentic contexts.

Ethical reasoning is involved in much of the decision-making that occurs in personal and professional lives which means that there is an abundance of material suited for selection as the basis of student learning and assessment activities. As a result of identifying a gap between students' responses to an ethical question posed in two different contexts - (Would they report another student for cheating? When on the job, would they report a colleague for falsifying reports?) - Steneck (1999, p. 4) suggests examples from the context of students' university experiences as a potentially engaging introduction to ethics and that the consideration of professionalism and professional codes is more effective if delayed until students are further into their professional course.

Many aspects of student life suggest issues and dilemmas that can be used to develop cases and questions for the application of ethical codes and the practice of ethical reasoning. These include Steneck's earlier question about cheating and variations on this theme (see for example Moon, 2005), group work behaviours such as social loafing and the issues raised in Taylor's letter to his students (e.g. 'putting yourself in a position to make fruitful contributions to class discussion', 'respecting other students' opinions', 'giving full and proper credit to sources').

While students can be actively engaged in the exploration of the ethical practices applicable to future professional life through many class-based activities, work placements, internships, service learning are real world contexts containing examples of ethical conflicts and competing values and therefore provide more authentic contexts for learning and assessment tasks (Balogh, 2002).

On broader ethical issues, print and electronic media are a rich source of material for the contextualisation of learning and assessment activities. Mladenovic (2009), for example, reported success in developing accounting students' ethical reasoning 
through following an ethical conflict resolution model and a variety of ethical perspectives to explore ethical issues reported in the press. Background material addressing the ethical issues associated with particular areas of professional practice (e.g. 'Accounting and auditing', 'Health and medicine') or topics of broader social significance (e.g. 'Globalisation', 'Indigenous issues'), readily available on the website of the St James Ethics Centre (see also Longstaff, 1995), constitutes a useful resource for academics and students.

Whatever the context in which learning and assessment are undertaken, it is important that independent, lifelong learning is encouraged and supported. Assessment needs to develop student knowledge and cognitive skills and their capacity to understand and apply meta criteria and standards to their own ethical reasoning practices and decisions and to those of others and this will only occur when they are active rather than passive participants in the assessment process (Boud, 2000).

\section{Conclusions}

It is as true for the development of ethics as for the development of any other GA critical thinking, communication, creativity - that teaching and assessment are most effective when a whole of programme approach is taken. While fragmented modules or courses will impact on student learning to some degree, the strongest message we can give students that the development of ethics is valued is for it to permeate an entire programme. The 'Ethics Audit' available through the Higher Education Academy's Centre for Bioscience (2008) website has been designed to "help teachers consider the content and design of a programme of learning with respect to the relevant ethical issues appropriate to the discipline".

This exploration of the assessment of ethics, while acknowledging the problematic nature of this undertaking and identifying key barriers, has argued that the development of ethics is too important to be left to chance. A range of literature has been drawn on to illustrate different orientations to the nature of ethics, types of assessment activities and contexts for learning and assessment. It has also been argued that the active engagement of students is essential to the success of this enterprise. (In the words of a student) the graduates of today are going to have to solve some very big problems tomorrow, things like energy, climate change, international relations (Burns, 2009). As ethical educators we need to determine and provide the best possible university experience that equips them to do it.

\section{Endnotes}

${ }^{1}$ This paper was originally presented at the $4^{\text {th }}$ Asia-Pacific Conference on Educational Integrity: Creating an Inclusive Approach, University of Wollongong, 2830 September 2009. It also appears in the Conference refereed proceedings and is reproduced here with the kind permission of the Editor, Professor Brian Martin.

${ }^{2}$ Conceptualisations of GAs as relating to work-readiness and employability are not listed separately here because 'work' is considered a context in which GAs are manifested rather than a context which requires its own distinctive attribute set.

\section{Author biography}

Clair Hughes is a Lecturer in Higher Education in the Teaching and Educational Development Institute at The University of Queensland. Her research and curriculum development projects have a particular focus on the scholarship of assessment for which she has been awarded a Citation for Outstanding Contribution to Student Learning from the Australian Learning and Teaching Council (ALTC). Clair, with 
colleagues from The University of Sydney and Griffith University, has recently completed an ALTC funded project which scoped curriculum and assessment practice around the implementation of graduate attributes in Australian universities.

\section{Acknowledgement}

The author is grateful to the reviewers, Nancy Matchett and Peter Bowden, and 4APCEI conference participants for the helpful and constructive comments they provided to inform the final shaping of this paper.

\section{References}

Association of American Colleges and Universities. (2009). Spring 2009 Draft for public release of ethical reasoning value rubric. Retrieved July 8, 2009, from http://www.aacu.org/value/rubricsshort/ethical reasoning.cfm.

Balogh, D. W. (2002). Teaching ethics across the psychology curriculum. Retrieved August 7, 2009, from http://www.psychologicalscience.org/teaching/tips/ tips 0902.cfm.

Barrie, S. (2004). A research-based approach to generic graduate attributes policy. Higher Education Research and Development, 23(3), 261-275.

Barrie, S. (2006). Understanding what we mean by the generic attributes of graduates. Higher Education, 51(2), 215-241.

Biggs, J. (2002). Guide for busy academics: Constructive alignment. Retrieved February 8, 2005, from http://www.heacademy.ac.uk/resources.asp? process $=$ full record\&section=generic\&id $=156$

Boud, D. (1998, 4-5 November). Assessment and learning - unlearning bad habits of assessment. Effective Assessment at University Conference. Retrieved March 2, 2007, from http://www.tedi.uq.edu.au/TEN/TEN previous/TEN2 99/ ten2 boud.html

Boud, D. (2000). Sustainable assessment: Rethinking assessment for the learning society. Studies in Continuing Education, 22(2), 151-167.

Burns, L. (2009). Plenary presented at Graduates for the 21st Century: The 2009 Enhancement Themes conference of the Scottish QAA. Retrieved August 7, 2009, from http://www.enhancementthemes.ac.uk/conference/video.asp.

Centre for Bioscience. (2008). Ethics audit incorporating sustainability. The Higher Education Academy. Retrieved August 6, 2009, from http:// www.bioscience.heacademy.ac.uk/ftp/resources/ethicsaudit.pdf.

de la Harpe, B., Thomas, J., Dalton, H., \& David, C. (2009). Understanding academic staff beliefs about graduate attributes: B-Factor Preliminary survey report. Australian Learning and Teaching Council. Retrieved September 23, 2009, from http://mams.rmit.edu.au/lo40udr8jzz2z.pdf.

Hughes, C., \& Barrie, S. (forthcoming). Influences on the assessment of graduate attributes in higher education. Assessment and Evaluation in Higher Education.

James, N., Hughes, C., \& Cappa, C. (forthcoming). Conceptualising, developing and assessing critical thinking in law. Teaching in Higher Education.

Kohlberg, L., Levine, C., \& Hewer, A. (1983). Moral stages: A current formulation and a response to critics. Basel, NY: Karger.

Knight, P. (2002). The assessment of complex learning outcomes. Paper presented at the International Conference on Engineering Education. Retrieved August 5, 2009, from http://www.ineer.org/Events/ICEE2002/Proceedings/Papers/Index/ O338-O340/O340.pdf .

Knight, P., \& Page, A. (2007). The assessment of 'wicked' competences: A report to the Practice-based Professional Learning Centre for excellence in teaching and learning in the Open University. Retrieved February 22, 2009, from http:// www.open.ac.uk/cetl-workspace/cetlcontent/documents/460d21bd645f8.pdf. 
Krathwohl, D. (2002). A revision of Bloom's taxonomy: An overview. Theory into Practice, 41(4), 212-218.

Krathwohl, D. R., Bloom, B. S., \& Masia, B. B. (1964). Taxonomy of educational objectives: The classification of educational goals. Handbook II: Affective domain. New York: David McKay Co.

Loacker, G. (Ed.). (2000). Self assessment at Alverno College. Milwaukee, Wis: Alverno Productions.

Longstaff, S. (1995). What is ethics education or training? St James Ethics Centre. Retrieved August 6, 2009, from http://www.ethics.org.au/about-ethics/ethicscentre-articles/ethics-subjects/education-and-training/article-0068.html.

Matchett, N. J. (2008). Ethics across the curriculum. In S. L. Moore (Ed.), New Directions for Higher Education: Practical approaches to ethics for colleges and universities, No. 142. (pp. 25-38). San Francisco: Jossey-Bass.

Mladenovic, R. (2009). Developing accounting students' ethical reasoning. Poster presentation at the Third National GAP symposium. The University of Sydney, July 13, 2009.

Moon, J. (2005). Plagiarism in higher education: An integrated approach: Workshop material. Retrieved August 6, 2009, from http://admin.exeter.ac.uk/academicl ugfaculty/staff/plagworkshop.doc.

Moore, S. L. (2008). Editor's notes. In S. L. Moore (Ed.), New directions for higher education: Practical approaches to ethics for colleges and universities, No. 142. (pp. 1-16). San Francisco: Jossey-Bass.

The National GAP Project website: http://www.itl.usyd.edu.au/projects/nationalgap/ introduction.htm

Perry, W. G. (1970). Forms of intellectual and ethical development in the college years: A scheme. New York: Holt, Rinehart and Winston.

St James Ethics Centre website: http://www.ethics.org.au/.

Snyder, B. (1973). The Hidden Curriculum. Cambridge: The MIT Press

Steneck, N. (1999). Designing teaching and assessment tools for an integrated engineering ethics curriculum. Paper presented at the 29th ASEE/IEEE Frontiers in Education Conference, San Juan, Puerto Rico.

Sumsion, J., \& Goodfellow, J. (2004). Identifying generic skills through curriculum mapping: A critical evaluation. Higher Education Research and Development, 23(3), 329-346.

Taylor, B. (n.d.). Academic integrity: A letter to my students. Retrieved August 5, 2009, from http://www.oakton.edu/user/ pboisver/NewFaculty/LetterTaylor.htm 